\title{
Radiation Shielding Properties of Mortars and Plasters Used in Historical Buildings
}

\author{
S. ÖZAVCi AND B. ÇETIN* \\ Amasya University, Sciences and Arts Faculty, Amasya, Turkey
}

\begin{abstract}
In this study, the radiation absorption properties of mortars and plasters used in historical buildings have been investigated. Studied lime concretes contained such additives as brick dust, fertilizer, wet lime, wool, egg white, bone meal, rice, casein, whey, bone ash and tree leaf juice, in different concentrations. The linear attenuation coefficients of gamma rays in lime concretes have been measured at 662, 1773 and $1332 \mathrm{keV}$. The gamma rays have been obtained from ${ }^{137} \mathrm{Cs}$ and ${ }^{60} \mathrm{Co}$ sources and the measurements have been performed using a gamma spectrometer, based on a $3^{\prime \prime} \times 3^{\prime \prime} \mathrm{NaI}(\mathrm{Tl})$ detector, connected to 16384-channel multi-channel analyser.
\end{abstract}

DOI: 10.12693/APhysPolA.132.986

PACS/topics: 28.52.Fa, 28.41.Qb

\section{Introduction}

With the introduction of radiation in many areas of technology, people are facing radiation hazards. Therefore, the development of different shielding materials is important for radiation protection. There are many studies that investigate the radiation shielding properties of different materials [1-9].

There are various materials, which can be used for shielding, such as building materials. In ancient times it was known that organic and inorganic materials help to improve the properties of building materials [10-13]. Therefore, in this study, radiation absorption properties of mortars and plasters, used in historical buildings, were investigated. For this purpose, different types of lime concrete have been developed to test radiation absorption.

\section{Methodology of research}

In the study, five different types of lime concrete have been manufactured using brick dust, fertilizer, wet lime, wool, egg white, bone meal, rice, casein, whey, bone ash and tree leaf juice. While the amount of wet lime was kept constant in the study, the proportions of additives, such as brick dust, fertilizer, wool, egg whites, bone meal, rice, casein, whey, bone ash and ash leaves, were changed. The content of the studied samples is summarized in Table I.

\section{TABLE I}

Content of the studied mortars and plasters.

\begin{tabular}{|c|c|c|c|c|c|}
\hline & N15 & N17 & N18 & N19 & N20 \\
\hline & 250.1 g wet lime & 250.5 g wet lime & $250.3 \mathrm{~g}$ wet lime & $250.3 \mathrm{~g}$ wet lime & 250 g wet lime \\
\hline & $100 \mathrm{~g}$ brick dust & $100 \mathrm{~g}$ brick dust & $100 \mathrm{~g}$ brick dust & $100 \mathrm{~g}$ brick dust & $100 \mathrm{~g}$ brick dust \\
\hline & $30 \mathrm{~g}$ bone ash & $5 \mathrm{~g}$ bepermo(chemical) & $5 \mathrm{~g}$ bepermo(chemical) & 5 g bepermo (chemical) & 5 g casein \\
\hline & 5 g casein & $35 \mathrm{~g}$ bone meal & $35 \mathrm{~g}$ bone meal & $35 \mathrm{~g}$ fertilizer & $63.47 \mathrm{~g}$ egg white \\
\hline & $65.15 \mathrm{~g}$ whey & $\begin{array}{l}4.6 \mathrm{~g} \text { wool } \\
44.8 \mathrm{~g} \text { whey }\end{array}$ & $37.5 \mathrm{~g}$ whey & $66.2 \mathrm{~g}$ disbudak tree leaf juice & $\begin{array}{l}15 \mathrm{~g} \text { rice } \\
18.2 \mathrm{~g} \text { whey }\end{array}$ \\
\hline
\end{tabular}

Linear attenuation coefficient is defined as the probability of interaction of radiation with the material, per unit path length [14-19].

The linear attenuation coefficients, $\mu\left(\mathrm{cm}^{-1}\right)$, of gamma rays in lime concrete have been measured at

\footnotetext{
*corresponding author; e-mail: betulcetin3205@gmail.com
}

gamma energy of 662,1773 and $1332 \mathrm{keV}$. The employed gamma rays have been emitted by ${ }^{137} \mathrm{Cs}$ and ${ }^{60} \mathrm{Co}$ sources, and the measurements have been performed using a gamma spectrometer (Fig. 1) which contains a $3^{\prime \prime} \times 3^{\prime \prime} \mathrm{NaI}(\mathrm{Tl})$ detector, connected to 16384-channel multi-channel analyser. Analysis of the resulting spectra was performed using MAESTRO software, version 7.01.

The linear attenuation coefficient is calculated using Beer-Lambert equation 


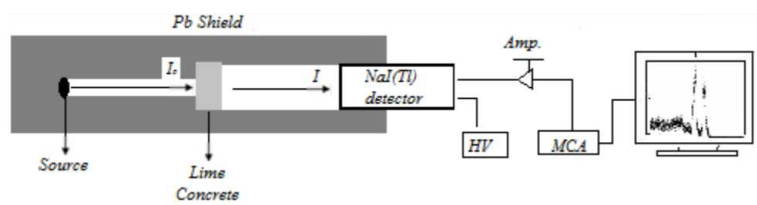

Fig. 1. The schematic view of experimental set-up.

$$
\mu=\frac{1}{x} \ln \frac{I_{0}}{I},
$$

where $\mu$ is the linear attenuation coefficient, $x$ is the thickness of the lime concrete, made with a mixture of mortars and plasters, $I_{0}$ and $I$ are incident and transmitted intensity.

\section{Results}

The values of linear attenuation coefficient were calculated for each sample and radiation attenuation characteristics were compared. The obtained linear attenuation coefficients for different energies and for different samples are shown in Table II and Fig. 2.

TABLE II

Linear attenuation coefficients.

\begin{tabular}{c|c|c|c|c|c}
\hline \hline N15 & N17 & N18 & N19 & N20 & Energy \\
\hline \multicolumn{5}{c}{$\left[\mathrm{cm}^{-1}\right]$} \\
\hline 0.0765 & 0.0789 & 0.0850 & 0.1225 & 0.0847 & 662 \\
0.0576 & 0.0603 & 0.0750 & 0.1082 & 0.0711 & 1173 \\
0.0576 & 0.0604 & 0.0721 & 0.1036 & 0.0700 & 1332
\end{tabular}
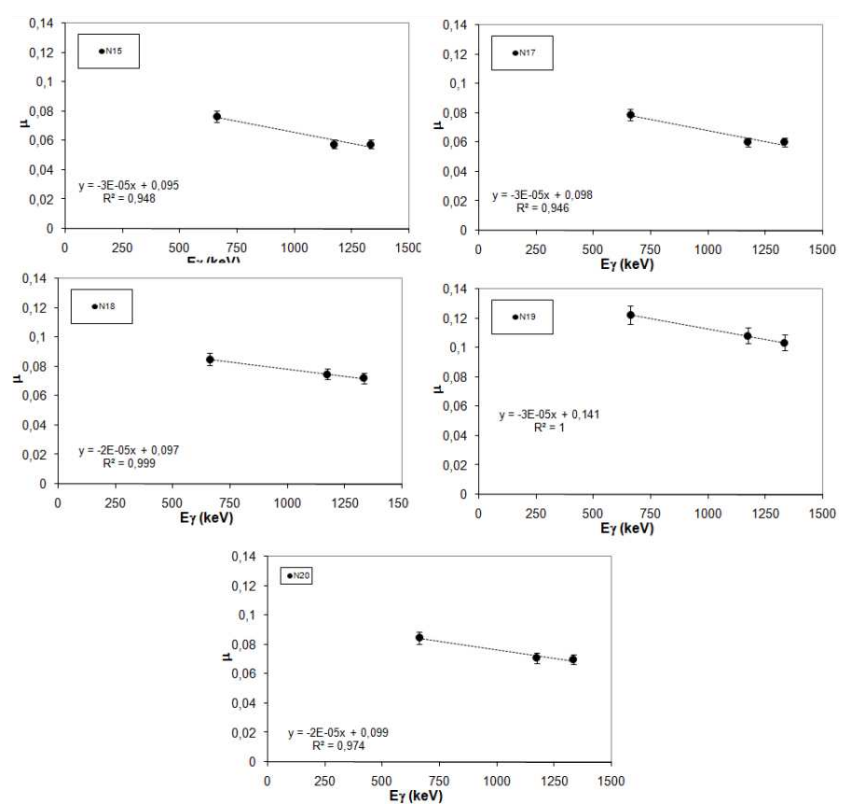

Fig. 2. Measured linear attenuation coefficients for lime concretes and $R^{2}$ values.

Linear attenuation coefficients as functions of energy are shown in Fig. 2. It can be seen from this figure that
N15 has a low attenuation coefficient at $662 \mathrm{keV}$ and $1173 \mathrm{keV}$ but N19 has a high attenuation coefficient at all energies. It can be concluded from this work that fertilizer and tree leaf juice increase linear attenuation coefficients of lime concrete. The $R^{2}$ values of the results are also given in Fig. 2, where it can be seen that the results are quite compatible.

\section{Acknowledgments}

This work has been supported by Scientific Research Projects Unit of Amasya University (FMB-BAP 15-095).

\section{References}

[1] I. Akkurt, S. Emikönel, F. Akarslan, K. Günoğlu, Ş. Kilinçarslan, İ.S. Üncü, Acta Phys. Pol. A 128, B-53 (2015).

[2] H. Mutuk, T. Mutuk, H. Gümüş, B. Mesci Oktay, Acta Phys. Pol. A 130, 172 (2016).

[3] B. Mavi, Ann. Nucl. Energy 44, 22 (2012).

[4] I. Akkurt, Ann. Nucl. Energy 36, 1702 (2009).

[5] M. Tapan, Z. Yalçın, O. İçelli, H. Kara, S. Orak, A. Özvan, T. Depci, Ann. Nucl. Energy 65, 290 (2014).

[6] I. Akkurt, H. Akyıldırım, Nucl. Engin Des. 252, 163 (2012).

[7] O. Gurler, U. Akar Tarim, Acta Phys. Pol. A 130 , 236 (2016).

[8] S. Özavc1, B. Çetin, Acta Phys. Pol. A 130, 316 (2016).

[9] B. Mavi, F. Oner, I. Akkurt, Acta Phys. Pol. A 128, B-395 (2015).

[10] B. İpekoğlu, H. Böke, M. Hamamcioğlu, S. Akkurt, Ö. Cizer, Tarihi Yapılarda Malzeme Bozulmasının Sinıflandırılmasıve Sorunların Saptanmasına Yönelik Bir Yöntem Araştırılması, TÜBİTAK Project No: 101I03, İzmir 2003.

[11] H. Böke, S. Akkurt, B. İpekoğlu, Yapı Dergisi 269, 90 (2004)

[12] Ö. Özgen, Horasan Harcı Üzerinde Deneysel Çalışmalar. Uzmanlık Tezi, Kültür ve Turizm, Bakanlı̆̆ İstanbul Rölöve ve Anıtlar Müdürlüğü, İstanbul 2012.

[13] I. Akkurt, H. Akyildirim, F. Karipcin, B. Mavi, J. Saudi Chem. Soc. 16, 199 (2012).

[14] J.I. Wood, Computational Methods in Reactor Shielding, Pergamon Press, 1982.

[15] İ. Akkurt, H. Akyıldırım, B. Mavi, S. Kılınçarslan, C. Başyiğit, Progr. Nucl. Energy 52, 620 (2010).

[16] I. Akkurt, C. Basyigit, S. Kilincarslan, B. Mavi, A. Akkurt, Cement Concrete Compos. 28, 153 (2006).

[17] I. Akkurt, Ann. Nucl. Energy 43, 56 (2012).

[18] B. Mavi, I. Akkurt, Acta Phys. Pol. A 128, B-370 (2015).

[19] I. Akkurt, H. Akyıldırım, B. Mavi, S. Kilincarslan, C. Basyigit, Ann. Nucl. Energy 37, 910 (2010). 